\title{
Spatial variability of close-to-primeval Fagus-Abies-Picea forests in the Western Carpathians (Central Europe): a step towards a generalised pattern
}

\author{
Jarosław G. Paluch $\cdot$ Zbigniew Kołodziej • \\ Maciej Pach · Rafał Jastrzębski
}

Received: 25 February 2014/Revised: 4 September 2014/ Accepted: 22 September 2014/Published online: 2 October 2014

(C) The Author(s) 2014. This article is published with open access at Springerlink.com

\begin{abstract}
The research objective was to provide a generalised model of spatial variation in the basal area of live and dead trees in primeval beech-fir-spruce forests in the Western Carpathians region. The study was carried out in three primeval stands located in the Polish part of the massif. In each research area, small sample plots ( 0.015 ha) were localised in a regular $20 \times 20 \mathrm{~m}$ grid covering approximately 10 ha. In each sample plot, the diameters at breast height $\left(d_{1.3}\right)$ and species of all live and dead trees were recorded. The spatial pattern was tested statistically using a variance-to-mean ratio on a single sample plot scale (0.015 ha) and a paired-plot approach for the distance range between 20 and $200 \mathrm{~m}$. Simulation techniques were then used to model variation in the basal area of live and dead trees dependent on spatial scale. The spatial patterns of live and dead canopy trees $\left(d_{1.3}>50 \mathrm{~cm}\right)$ were regular when analysed on a single sample plot scale ( 0.015 ha) but most often random at distance lags $\geq 20 \mathrm{~m}$. The spatial variability in the basal area of live and dead trees also tended to be random. These results suggest that the patchmosaic assumption is inapplicable to the primeval beechfir-spruce stands in the Western Carpathians. In all three
\end{abstract}

Communicated by J. Müller.

J. G. Paluch $(\bowtie) \cdot$ Z. Kołodziej · M. Pach · R. Jastrzębski Faculty of Forestry, Agricultural University, Al. 29 Listopada 46, 31-425 Cracow, Poland

e-mail: jpaluch@ur.krakow.pl

Z. Kołodziej

e-mail: rlkolodz@cyf-kr.edu.pl

M. Pach

e-mail: rlpach@cyf-kr.edu.pl

R. Jastrzębski

e-mail: rjastrzebski@ur.krakow.pl stands studied, the basal area recorded on the plots 0.015 ha in area had a very similar pattern of variation, which could be generalised as either a truncated normal distribution (live trees) or a negative exponential distribution (dead trees). The bell-shaped frequency distribution of the basal area of live trees suggests a dynamics model in which extreme values of biomass accumulation are rare and disturbances frequent but quickly balanced by stand increment.

Keywords Gap dynamics - Patch mosaic .

Developmental cycle $\cdot$ Steady-state conditions $\cdot$ Spatial pattern $\cdot$ Structural diversity

\section{Introduction}

Over recent centuries, the species composition of almost all European forest ecosystems has changed and their structural diversification decreased. The natural stands of shadetolerant European beech (Fagus sylvatica), silver fir (Abies $a l b a$ ), and Norway spruce (Picea abies), formerly widespread in the mountain regions (Mayer and Ott 1991), exist today only in relic form in a few locations in central and south-eastern Europe (Mayer 1986; Korpel' 1993; Veen et al. 2010). The dynamics of such forests is driven by disturbances of minor intensity that kill single or eventually small groups of trees (Standovár and Kenderes 2003; Splechtna et al. 2005; Zeibig et al. 2005; Nagel and Svoboda 2008; Firm et al. 2009; Trotsiuk et al. 2012) and favour multilayered stand structures (Commarmot et al. 2005; Westphal et al. 2006; Kucbel et al. 2010; Šebková et al. 2011; Motta et al. 2011). Knowledge about the structure and dynamics of these forests may provide a foundation for activities to recreate such communities in 
areas where nature conservation and biodiversity protection are a priority (Winter and Brambach 2011; Winter 2012). It may also be useful as a model for close-to-nature silviculture (Meyer et al. 2003; Jaworski 2004; Bauhus et al. 2009).

To date, the research carried out on natural, mixed, or pure beech forests has focused on stand structure (e.g. von Oheimb et al. 2005; Piovesan et al. 2005; Westphal et al. 2006; Alessandrini et al. 2011), changes in species composition (Vrška et al. 2009), regeneration (Nagel et al. 2006; Roženbergar et al. 2007), coarse woody debris (Christensen et al. 2005), stand dynamics (Jaworski and Paluch 2002; Šebková et al. 2011), gap dynamics (Kenderes et al. 2009), and reconstruction of natural disturbances (Splechtna et al. 2005; Zeibig et al. 2005; Nagel and Svoboda 2008; Firm et al. 2009; Trotsiuk et al. 2012). Only a handful of studies have profiled the spatial variability of the structural attributes in stand patches representative to steady-state conditions; that is, large enough to buffer the effects of natural disturbances and guarantee demographic equilibrium at an approximately constant biomass accumulation level (Dziewolski 1991; Holeksa et al. 2009; Šebková et al. 2011). As a result, even the most basic characteristics of these stands, such as the range of variation in structural attributes or the minimal area for shifting mosaic steady-state conditions, remain a subject of discussion (Korpel' 1993; Emborg et al. 2000; Piovesan et al. 2005; Paluch 2007; Král et al. 2010a, b).

This scarcity of empirical studies focused on the spatial pattern of primeval stands in larger areas contrasts starkly with the widespread acceptance of a patch-mosaic paradigm (Leibundgut 1993; Korpel' 1993) that views naturally developing stands as coarse-grained mosaics of integral stand patches, typically of several hundred square meters, that represent different stages of a developmental cycle (Remmert 1991; Otto 1994; Podlaski 2008; Král et al. 2010b). Although the terminology used to categorise these stages may differ according to classification system, in general, the systems distinguish between long periodsusually over 100 years - of biomass accumulation and biomass reduction. The developmental cycle itself may be deterministically (Korpel' 1993) or more stochastically defined (Emborg et al. 2000).

The patch-mosaic hypothesis, although attractive for its simplicity and elegance, seems difficult to defend either from a purely theoretical viewpoint or in the face of gradually accumulating empirical facts. The most controversial element is an assumption of patchy (non-random) disintegration in the canopy layer, which may allegedly lead to spatio-temporal synchronisation of regenerative and recruitment processes and in the longer term to senescence and break-up processes (Leibundgut 1993; Korpel' 1993). This reasoning, however, can neither explain the non- random course of canopy disintegration process nor identify its primary cause because in forests dominated by beech, only small gaps are created in most cases, with larger gaps usually containing retained trees and gap expansion playing only a minor role (Standovár and Kenderes 2003; Zeibig et al. 2005; Nagel and Diaci 2006). In fact, most studies to date have questioned the validity of a hypothesis that assumes a non-random spatial pattern of live and dead canopy trees (Szwagrzyk and Czerwczak 1993; Szwagrzyk et al. 1997; von Oheimb et al. 2005; Splechtna et al. 2005; Paluch 2007; Šebková et al. 2011) even though the spatial range they consider enables only soft falsification of a general assumption. Moreover, in structured forests, single trees may exhibit major differences in life trajectories because of shading-release sequences (Szwagrzyk and Szewczyk 2001; Nagel and Diaci 2006; Trotsiuk et al. 2012) and the impact of biotic destructive factors (e.g. fungi responsible for trunk rot) (von Oheimb et al. 2005; Zeibig et al. 2005; Trotsiuk et al. 2012). In these cases, the relation between tree age and mortality rate seems too weak to fully control gap dynamics and tree generation replacement.

Hence, in an extension of a pilot project in the Łabowiec reserve (Paluch 2007), the oldest reserve in the Polish part of the Western Carpathians, the analysis reported here examined the spatial variability of basic structural attributes in three other well-preserved primeval stands of European beech, silver fir, and Norway spruce. Specifically, it focused on the variation in the basal area of live and dead trees, the distribution patterns of different size classes of trees, and the vertical differentiation of the forest structure on spatial scales ranging from an area corresponding to an average parcel of a canopy tree up to several hectares. The research objective was twofold: (1) to test the hypothesis of a non-random aggregated spatial pattern of live and dead canopy trees and a patch-mosaic pattern of stand basal area in natural beech-fir-spruce forests and (2) to depict the variation in the structural attributes analysed in the generalised form of probability models.

\section{Methods}

\section{Study area}

The study was conducted in three reserves in which the best preserved forests within the Polish part of the Western Carpathians are strictly protected. The reserves selected represent the western ("Żarnowka" reserve, $49^{\circ} 35^{\prime} 34^{\prime \prime} \mathrm{N}$ $19^{\circ} 33^{\prime} 14^{\prime \prime} \mathrm{E}$; hereafter, Stand I), middle ("Baniska" reserve, $49^{\circ} 27^{\prime} 38^{\prime \prime} \mathrm{N} 20^{\circ} 36^{\prime} 46^{\prime \prime} \mathrm{E}$; hereafter, Stand II), and eastern ("U źródeł Solinki" reserve, $49^{\circ} 6^{\prime} 18^{\prime \prime} \mathrm{N}$ $22^{\circ} 32^{\prime} 51^{\prime \prime} \mathrm{E}$; hereafter, Stand III) parts of the Western 
Carpathians. At present, Stand I and Stand III are within the borders of the Babia Góra and Bieszczadzki National Parks, respectively, while Stand II is enclosed in a strict reserve of almost 142 ha surrounded by managed state forests. The period for which each reserve has been strictly protected differs: since 1916, 1934, and 1956 for Stand II, Stand I, and Stand III, respectively. This factor, however, cannot be treated as a measure of their naturalness because in all reserves, the primary reason for protection was the high level of preservation of natural stands stemming probably from terrain inaccessibility, past patterns of extensive forest land utilisation, and the economic infeasibility of logging. Even so, the term "primeval" is used here to underscore that the selected stands bear no signs of direct human activity (stumps, cut trees, logging trails, under-planting, simplified vertical stand structure). Nevertheless, given the long period of settlement in the West Carpathians (since the fifteenth century), plunder-like cuttings of single trees may have occurred in the past. Also to be considered are the indirect effects of human activity that resulted in over-density of ungulate populations and air pollution that led to changes in species composition (Vrška et al. 2009; Homolka and Heroldová 2003).

The core zone of each reserve contained one research area (about $10 \mathrm{ha}$ ) selected for its homogeneity of site and terrain orography and freedom from signs of direct human activity. No additional assumption was made about stand structure or species composition. All research areas were close to rectangular, with side proportions between $1: 1$ and 1:1.6. All were situated in the upper zone of the lower montane belt between 900 and $1040 \mathrm{~m}$ a.s.1. on the northern (Stand I), north-eastern (Stand II), and eastern (Stand III) slopes, with inclinations of $10^{\circ}-20^{\circ}, 15^{\circ}-25^{\circ}$, and $5^{\circ}-15^{\circ}$, respectively. At the altitude corresponding to the location of the stands studied, the vegetation period is approximately 180-200 days, the mean annual temperature is $5-7^{\circ} \mathrm{C}$, and the annual precipitation is $900-1,450 \mathrm{~mm}$, reaching a maximum in the summer months (Paszyński and Niedzwiedź 1999). The precipitation increases with altitude and from east to west. The prevalent soils in the research areas are loamy dystric or eutric cambisols developed on flysch bedrock (sandstones and shales); the dominant tree cover is a Dentario glandulosae-Fagetum association built mainly of beech (Fagus sylvatica L.), fir (Abies alba Mill.), and, except in Stand III, also spruce (Picea abies Karst.). The proportion of spruce decreases from west to east because of the increasingly continental climate and the lower altitude of the mountain ranges.

\section{Field measurements}

To enable result comparability, the present study retained the same sampling scheme and computational approach used in the pilot project (Paluch 2007). In each research area (hereafter, stand), a grid of perpendicular axes distanced by $20 \mathrm{~m}$ was traced out onto whose nodes were placed (between 237 and 267) sample plots with a 7.0 m radius. As evidenced by later analyses, the size of these plots corresponded approximately to a parcel of single canopy trees $\left(d_{1.3} \geq 50 \mathrm{~cm}\right.$, mean density between 0.9 and 1.2 per plot). Within each plot were recorded the diameter at breast height $\left(d_{1.3}\right)$ and species of all live trees of $d_{1.3} \geq 7 \mathrm{~cm}$ and $d_{1.3}$ of all dead trees of an approximated $d_{1.3} \geq 15 \mathrm{~cm}$, together with their species when possible. For methodological coherence, the trees were divided as in the earlier study (Paluch 2007) into canopy trees $\left(d_{1.3} \geq 50 \mathrm{~cm}\right)$, sub-canopy trees $\left(25 \mathrm{~cm} \leq d_{1.3}<50 \mathrm{~cm}\right)$, and under-canopy trees ( $\left.7 \mathrm{~cm} \leq d_{1.3}>25 \mathrm{~cm}\right)$. The dead tree definition included standing dead trees, snaps, fallen snaps, and uprooted trees, whose $d_{1.3}$ had to be approximated in the case of missing bark, advanced decay, or split logs. These dead trees were divided into three decay categories: class A: recently dead trees (within ca. 5 years) that retained thin twigs and adhering bark; class B: trunks partly without bark and slightly decomposing but still compact wood; and class C: snaps, fallen snaps, and remnants of uprooted trees with soft wood in advanced decay that often made the distinction between the species impossible. To approximate the relation between $d_{1.3}$ and tree height, for each species at least 100 height measurements were carried out exact to $0.1 \mathrm{~m}$ with Vertex IV device (Haglöf, Sweden).

\section{Data analysis}

The measurements carried out allowed determination of the number and basal area of live and dead trees (hereafter, $\mathrm{BA}_{\mathrm{L}}$ and $\mathrm{BA}_{\mathrm{D}}$, respectively). As a measure of structural diversification, the simple variance in tree height was computed and scaled through comparison with a hypothetical variance of the uniform distribution (hereafter, the differentiation index, abbreviated $\mathrm{VAR}_{\mathrm{h}}$ ). Tree heights (h) were approximated by the regression $h=d_{1.3}^{2}\left(\mathrm{a}_{0}+\mathrm{a}_{1}\right.$ $\left.d_{1.3}+\mathrm{a}_{2} d_{1.3}^{2}\right)^{-1}-1.3$ with the following coefficient vectors $\left(\mathrm{a}_{0}, \mathrm{a}_{1}\right.$, and $\left.\mathrm{a}_{2}\right)$ : $(-1.095,0.827,0.0179)$ for beech (10.004,0.495,0.019) for fir, and $(3.506,0.806,0.015)$ for spruce. Because the $d_{1.3}-h$ relation is only approximate and the differences between stands are small, the same set of coefficients was used in all stands. The uniform distribution used in the calculation of the differentiation index was constrained by the values 6 and $40 \mathrm{~m}$, which correspond approximately to the average height of the smallest and largest trees in the data set.

In general, $\mathrm{VAR}_{\mathrm{h}}$ depends on the shape, mean, and variation of the diameter distribution, increasing from onemodal to two-modal distribution as variation increases and the mean decreases. For example, for a beech collective 
with a normal diameter distribution of a $25 \mathrm{~cm}$ mean and 7 or $15 \mathrm{~cm}$ standard deviation, $\mathrm{VAR}_{\mathrm{h}}$ is 0.12 or 0.33 , respectively. For the reverse $J$-shaped distribution with a $25 \mathrm{~cm}$ mean and $15 \mathrm{~cm}$ standard deviation (given by a de Liocourt quotient of about 0.90 ), $\mathrm{VAR}_{\mathrm{h}}$ is 0.77 . For the uniform distribution, $\mathrm{VAR}_{\mathrm{h}}$ is 1 ; and for bimodal distributions, it is more than 1 . The $\mathrm{VAR}_{\mathrm{h}}$ value also depends on the $d_{1.3}-h$ relation, although this effect is minor compared with the above factors.

The spatial distribution patterns of trees were analysed using a two-step procedure. First, the dispersion index $I$, a sample variance-to-mean ratio, was computed for the single sample plots (i.e. for a spatial scale of $0.015 \mathrm{ha}$ ). The product $I(N-1)$, where $N$ denotes the number of sample plots, was then used as a test statistic in a random labelling test in which the recorded trees were randomly assigned to sample plots in 1,000 simulations. $P$ values were then derived by ranking the empirical $I$ values among the simulation values. The $I$ values greater (less) than 1 indicated a tendency for clustered (regular) patterns. The second step, designed to take advantage of the known location of the sample plots, adopted a paired-plot approach (Cressie 1991) in which the mean square for the plots separated by $r$ grid units $(=20 \mathrm{~m})$ is

$V_{r} \equiv \frac{1}{n_{r}} \sum_{i=1}^{n_{r}}\left(A_{i}-B_{i}\right)^{2}$.

Here, $A_{i}$ and $B_{i}$ are the number of events in the $i$ th pair of the plots $r$ grid units apart, and the sum is over all distinct $n_{r}$ pairs of the plots separated by $r$ units. Given the shape of the research areas, $200 \mathrm{~m}$ (i.e. $r=10$ ) was the maximal inter-plot distance analysed. Under random arrangement of plot counts, the variance estimates could be expected to be roughly constant (Cressie 1991). Low mean square values indicate relative similarity between the plots separated by $r$ units (i.e. positive spatial correlation), and in general, patch-mosaic patterns should result in the closest plots having the lowest mean square values with gradual increases as the plots become more separated.

The empirical mean squares were then compared with $95 \%$ simulation envelopes for 1,000 randomisations of the plot counts. In this procedure, the plot counts were randomly assigned to the sample plots, then $V_{r}$ was calculated, and the lower and upper simulation envelopes were designated as the 25th and 975th, respectively, based on the ascending order of $V_{r}$ values. As a measure of the discrepancy between the empirical variance estimates $\hat{V}_{r}$ and the expectations under the random arrangement of plot counts $\bar{V}_{r}$, the following $U$ measure was defined:

$U=\frac{1}{k} \sum \frac{2\left(\bar{V}_{r}-\hat{V}_{r}\right)}{W_{r}}$, where the summation is over all $r$ units for which $\hat{V}_{r}$ is beyond the $95 \%$ simulation envelope if this condition holds or over all $r$ units, $r=1,2, \ldots, 10$, otherwise. $k$ is the number of $r$ units in the sum, $\bar{V}_{r}$ is the mean obtained from the simulations, and $W_{r}$ is the width of the estimated $95 \%$ confidence interval. Under such a formulation, $U$ values greater than 1 or lower than -1 denote a significant positive or negative spatial correlation between plot counts, while intermediate values indicate a stronger (weaker) tendency towards aggregated (regular) patterns. For any of the distance classes, the deviance is statistically significant at the 0.05 level.

As regards $\mathrm{BA}_{\mathrm{L}}, \mathrm{BA}_{\mathrm{D}}$, and $\mathrm{VAR}_{\mathrm{h}}$, a paired-plot approach was used in which the plot counts were replaced by the basal area of live/dead trees or the differentiation index, respectively. The results of computing the number of events in the distinct pairs of plots $r$ grid units apart were then compared with those from an alternative computation of the mean squares for all distinct pairs of plots separated by $r$ or less units. Because the results were very similar, only the first approach is considered from here on.

\section{Simulative approach}

To provide a more general view of the spatial variation in the stand basal area, the empirical frequency distributions of $\mathrm{BA}_{\mathrm{L}}$ and $\mathrm{BA}_{\mathrm{D}}$ from the three stands studied here were combined with those from the pilot project (Paluch 2007). Probability density functions were then fitted to the $\mathrm{BA}_{\mathrm{L}}$ and $\mathrm{BA}_{\mathrm{D}}$ distributions using a maximum likelihood criterion and a truncated normal distribution model for live trees and a negative exponential model for dead trees. These functions were then applied in simulations designed to model and compare variation in $\mathrm{BA}_{\mathrm{L}}$ and $\mathrm{BA}_{\mathrm{D}}$ on three arbitrarily selected spatial scales of $0.1,1.0$, and 5.0 ha. In this simulation procedure, the distributions were obtained by drawing a requested number of samples $N(N=A / a$, $A=0.1,1.0$, or 5.0 ha, $a=$ the area of the single sample plot; i.e. ca. $154 \mathrm{~m}^{2}$ ) according to the fitted probability density functions.

Because this approach did not account for the possible effects of spatial correlation, however, the results from the direct sampling were also compared with those from a twolevel sampling. First, in the given research area, a random sample plot $X$ was drawn from the whole grid, and then $k^{2}$ sample plots were randomly drawn (with replacement) from the surroundings of $X$, defined as a block of $(k+1) \times(k+1)$ plots centred at $X$. This step was repeated until a sample number $N$ was obtained that corresponded to the spatial scale being tested. $k$ was fitted to cover the range of the spatial correlation, and a toroidal shift method was applied to control for border effects. 
Admittedly, because the simulations treat the plots as adjacent (whereas in the empirical set, the midpoints of the plots with a $7 \mathrm{~m}$ radius are distanced by $20 \mathrm{~m}$ ), both the above procedures are subject to a risk of underestimating the spatial correlation at the inter-plot distances of neighbouring plots. The importance of this effect, however, should not be over-estimated given that even in the basic sample plots (those with a $7 \mathrm{~m}$ radius), the "repulsion" between canopy trees, expressed as a variance-to-mean ratio, was about $0.7-0.8$ and thus little lower than would be expected was the distribution random (i.e. a variance-tomean ratio equal to 1 ). Nevertheless, even a weak negative spatial correlation on the neighbouring plots scale would tend to decrease spatial variation for the patch sizes analysed $(0.1,1.0$, and $5.0 \mathrm{ha})$, meaning that the spatial variation in $\mathrm{BA}_{\mathrm{L}}$ and $\mathrm{BA}_{\mathrm{D}}$ obtained from the simulations may eventually become insignificantly positively biased.

The above-described approach in a modified form was also applied in regards to $\mathrm{VAR}_{\mathrm{h}}$. Because the differentiation index is not cumulative, the distributions in this modified version were obtained by randomly drawing a requested number of sample plots $N$ from the empirical data and $\mathrm{VAR}_{\mathrm{h}}$ was then calculated jointly for all the trees from the sample plots drawn, that is, for patches $0.1,1.0$, or 5.0 ha, depending on the spatial scale considered. Because of the random pattern of intra-stand variation in $\mathrm{VAR}_{\mathrm{h}}$, the effect of spatial correlation could be ignored.

\section{Results}

Species composition, basal area and diameter distributions

The partition of beech in $\mathrm{BA}_{\mathrm{L}}$ decreased from east to west, being highest in Stand III (84\%) and lowest in Stand I (44\%) (Table 1). Spruce had the highest partition in Stand I (26\%) but was absent in Stand III, while the partition of fir ranged between $16 \%$ (Stand III) and $33 \%$ (Stand II). Overall, in spite of considerable differences in species composition, the $\mathrm{BA}_{\mathrm{L}}$ values were very similar, with a range between 36.1 and $38.4 \mathrm{~m}^{2} / \mathrm{ha}$ (Table 1). In all cases, the diameter distributions for all the species pooled together had a rotated sigmoidal form, with the highest number of small trees and a slightly marked local maximum in diameter classes of about $60 \mathrm{~cm}$ (Fig. 1). Stem density, on the other hand, differed significantly between stands, ranging from 288 to 682 trees per ha (Table 1). The largest differences occurred among small trees: the stem density of trees above $30 \mathrm{~cm}$ in diameter differed by only $20 \%$, with a range between 139 and 173 trees per ha.

The stem density of dead trees was very similar, with a range between 143 and 160 per ha (Table 2, Fig. 2). The
Table 1 Characteristics of live trees in the three stands studied

\begin{tabular}{lccl}
\hline Characteristics & Stand I & Stand II & Stand III \\
\hline Number of sample plots & 259 & 237 & 267 \\
Stem density (N/ha) & & & \\
Abies & 45 & 87 & 36 \\
Fagus & 188 & 573 & 414 \\
Picea & 54 & 22 & - \\
Total & 288 & 682 & 450 \\
Basal area $\mathrm{BA}_{\mathrm{L}}\left(\mathrm{m}^{2} / \mathrm{ha}\right)$ & & & \\
Abies & 10.6 & 12.1 & 6.3 \\
Fagus & 16.0 & 24.0 & 32.1 \\
Picea & 9.5 & 1.0 & - \\
Total & 36.1 & 37.1 & 38.4 \\
Volume $\left(\mathrm{m}^{3} / \mathrm{ha}\right)$ & & & \\
Abies & 154 & 168 & 86 \\
Fagus & 130 & 301 & 437 \\
Picea & 238 & 9 & - \\
Total & 522 & 478 & 523 \\
\hline
\end{tabular}

Explanation: $d_{1.3} \geq 7 \mathrm{~cm}$. The stand volume was estimated based on stand- and species-specific diameter-height relations and volume tables (Grundner and Schwappach 1952)

$B A_{D}$ values increased with the increasing portion of coniferous species in the stand species composition-from $20.2 \mathrm{~m}^{2} / \mathrm{ha}$ in Stand III up to $28.0 \mathrm{~m}^{2} / \mathrm{ha}$ in Stand I (Table 2)—and accounted for between $53 \%$ (Stand III) and $77 \%$ (Stand I) of $\mathrm{BA}_{\mathrm{L}}$.

Spatial patterns: live and dead trees and basal area

On the single plot scale ( $0.015 \mathrm{ha})$, the distributions of live trees deviated from randomness towards clumped patterns (Table 3), a tendency maintained in Stand III and Stand II up to a distance of $20 \mathrm{~m}$ and in Stand I up to $80 \mathrm{~m}$ (Table 4). The effect of aggregation was attributable only to under-canopy trees $\left(d_{1.3}<25 \mathrm{~cm}\right)$, while the distribution of canopy trees $\left(d_{1.3}>50 \mathrm{~cm}\right)$ was regular on the single plot scale but random on the larger spatial scales (Tables 3, 4).

Except in Stand II, the distribution of dead trees (all decay classes, $d_{1.3} \geq 15 \mathrm{~cm}$ ) was random on the single plot scale (Table 3), but in the larger distance classes, clumped patterns were observed (Table 4). However, the dead canopy trees (all decay classes, $d_{1.3} \geq 50 \mathrm{~cm}$ ) were randomly distributed (Table 4).

On the single plot scale, the frequency distributions of $\mathrm{BA}_{\mathrm{L}}$ took the form of a truncated normal distribution (Fig. 3a) with a maximal frequency between 0.35 and $0.65 \mathrm{~m}^{2}$ per 0.015 ha and variation coefficients between 0.54 and 0.67 . This result was also valid for the pilot study data from the Łabowiec reserve (Paluch 2007). Modelled 
Fig. 1 Diameter distributions of live trees in the three stands studied
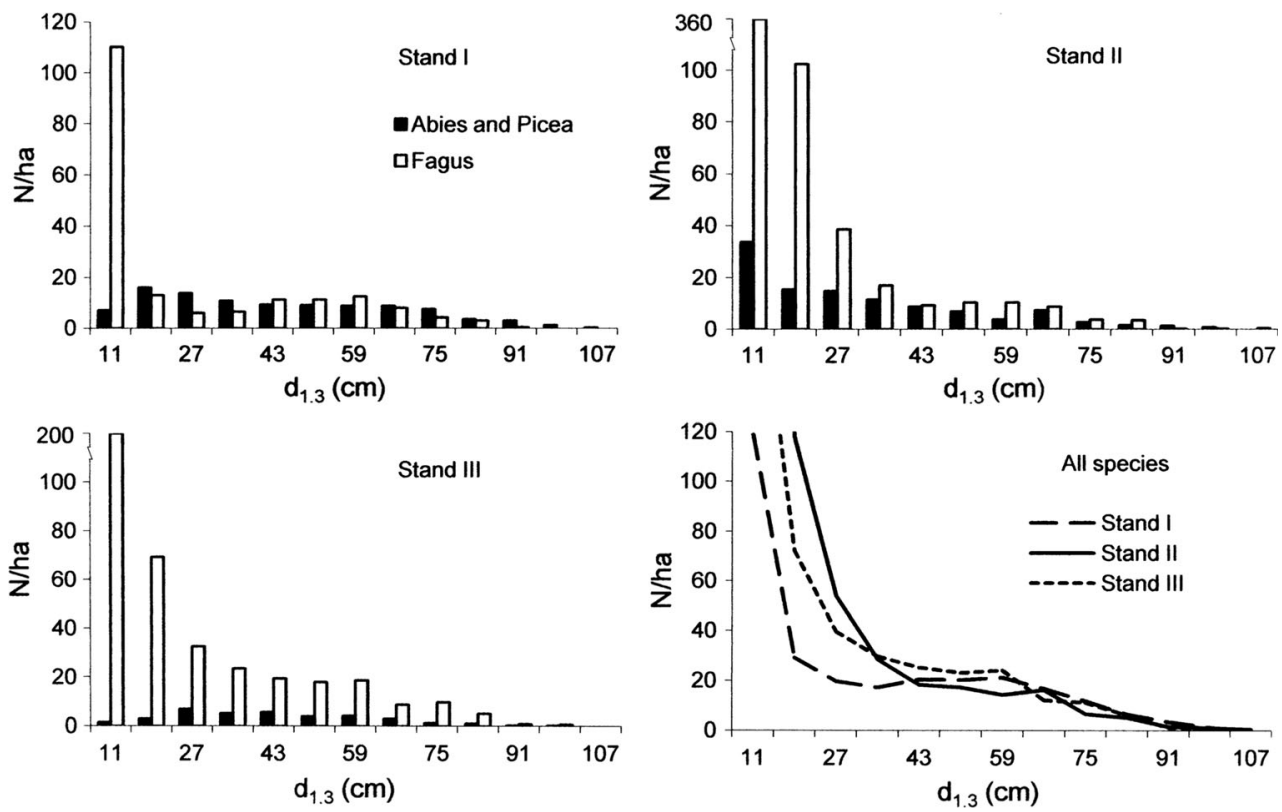

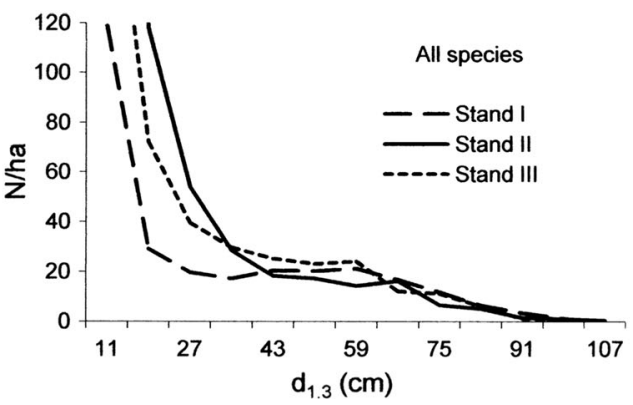

Table 2 Characteristics of dead trees in the three stands studied

\begin{tabular}{lccl}
\hline Characteristics & Stand I & Stand II & Stand III \\
\hline Stem density (N/ha) & & & \\
$\quad$ Abies & 26 & 64 & 57 \\
Fagus & 14 & 28 & 48 \\
Picea & 65 & 13 & - \\
Unspecified & 38 & 55 & 44 \\
Total & 143 & 160 & 149 \\
Basal area BA $\left(\mathrm{m}^{2} / \mathrm{ha}\right)$ & & & \\
Abies & 5.9 & 10.8 & 6.7 \\
Fagus & 2.6 & 3.0 & 7.5 \\
Picea & 12.6 & 0.6 & - \\
Unspecified & 6.9 & 10.8 & 6.0 \\
Total & 28.0 & 25.2 & 20.2 \\
\hline
\end{tabular}

Explanation: $d_{1.3} \geq 15 \mathrm{~cm}$

distributions of $\mathrm{BA}_{\mathrm{L}}$ and variation coefficients dependent on spatial scale are shown in Fig. 3c, e.

The spatial distribution of $\mathrm{BA}_{\mathrm{L}}$ was random in Stand II and Stand III no matter whether all trees $\left(d_{1.3} \geq 7 \mathrm{~cm}\right)$ or only canopy trees $\left(d_{1.3} \geq 50 \mathrm{~cm}\right)$ were taken into account (Table 5). For the distance classes less than $60 \mathrm{~m}$, this pattern also prevailed in Stand I. As indicated by the simulation study (the two-level sampling described in the Methods section), the small deviations revealed in Stand I for the distance classes above $60 \mathrm{~m}$ did not significantly influence the estimated variation in $\mathrm{BA}_{\mathrm{L}}$ (i.e. these shown in Fig. 3c, e). This latter was similar in both the two-level sampling, which takes spatial correlation into account, and the simple sampling, which assumes random patterns.
The frequency distributions of $\mathrm{BA}_{\mathrm{D}}$ differed substantially from those of live trees, exhibiting a form of negative exponential distributions with maximal frequency in the plots with a small basal area (Fig. 3b). This finding also echoes the results from the Łabowiec pilot project. The variation coefficients for single sample plots ranged between 0.83 (Stand I) and 0.93 (Stand III) and were higher than the variation in $\mathrm{BA}_{\mathrm{L}}$ irrespective of spatial scale (Fig. 3e). As the spatial scale increased, however, the variation decreased at a very similar rate (plot area to the power of -0.49 ) for both live and dead trees.

On the scale below $40 \mathrm{~m}$, in all stands, the spatial distribution pattern of $\mathrm{BA}_{\mathrm{D}}$ was classifiable as random no matter whether all trees $\left(d_{1.3} \geq 15 \mathrm{~cm}\right)$ or only canopy trees $\left(d_{1.3} \geq 50 \mathrm{~cm}\right)$ were considered (Table 5). In Stand II, this pattern was maintained over the entire range of spatial scales analysed, while in Stand I and Stand III departures towards aggregated or regular patterns were found in the distance range between 40 and $100 \mathrm{~m}$. To check the effect of this spatial correlation on the association between spatial scale and variation in $\mathrm{BA}_{\mathrm{D}}$ (shown in Fig. 3d, e), a simulation using two-level sampling was again conducted on the data from Stand I and Stand III. The results indicate that the differences in variation coefficient estimated for the simple and two-level sampling procedure were below 0.01 , meaning they can be ignored.

\section{Vertical differentiation}

When the diameter distribution for the entire stand was taken into account (Fig. 1), $\mathrm{VAR}_{\mathrm{h}}$ was 0.53 in Stand II, 0.69 in Stand III, and 1.01 in Stand I. The lowest value was 
Fig. 2 Diameter distributions of dead trees in the three stands studied
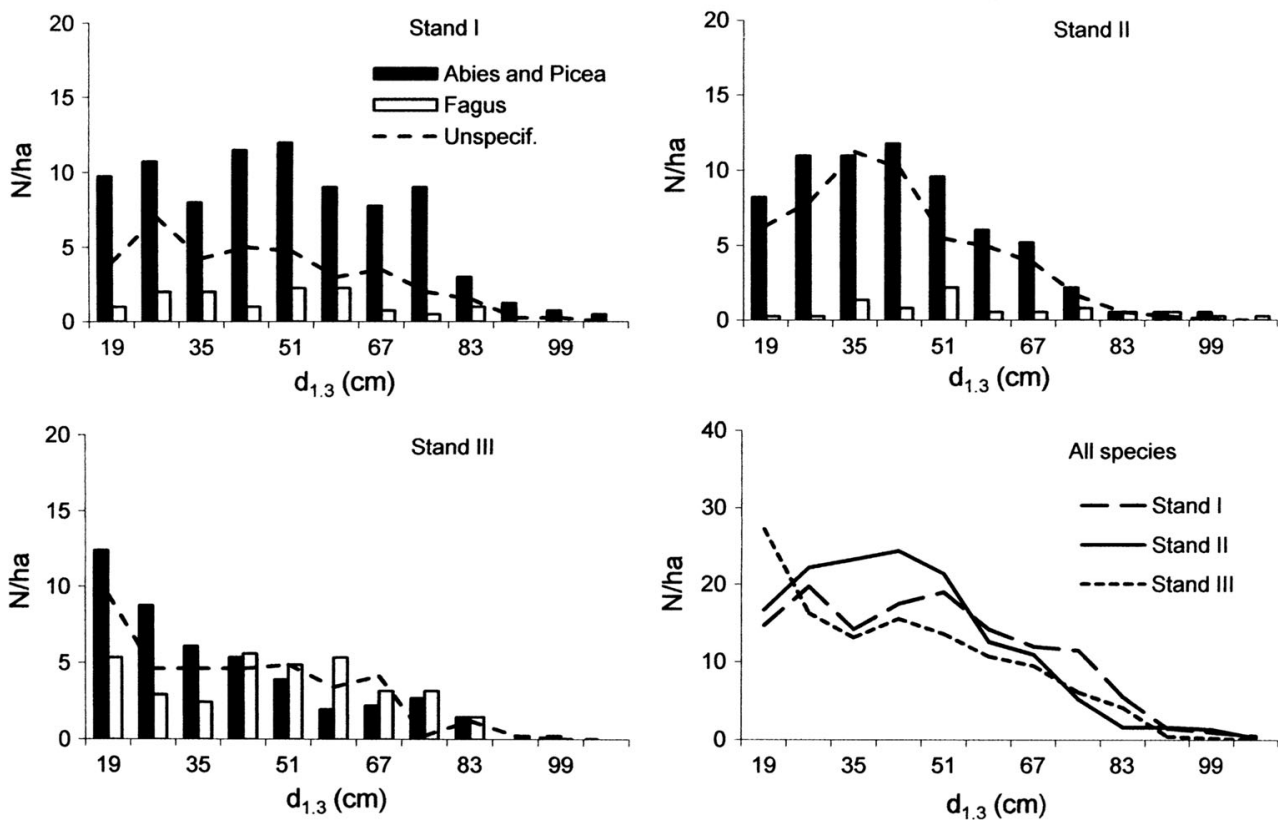

Table 3 Variance-to-mean ratio of the plot counts of live and dead trees on sample plots 0.015 ha in area

\begin{tabular}{|c|c|c|c|c|c|c|c|}
\hline Live/dead trees (decay class) & Size categories & $\mathrm{N} / \mathrm{ha}$ & Stand I & N/ha & Stand II & $\mathrm{N} / \mathrm{ha}$ & Stand III \\
\hline \multirow[t]{3}{*}{ Live trees } & All & 288 & $1.5(<0.001)$ & 682 & $2.3(<0.00 .1)$ & 450 & $1.3(0.002)$ \\
\hline & Under-canopy trees & 150 & $1.4(0.002)$ & 526 & $3.0(<0.001)$ & 282 & $2.1(<0.001)$ \\
\hline & Canopy trees & 75 & $0.8(0.002)$ & 58 & $0.7(<0.001)$ & 72 & $0.8(0.005)$ \\
\hline \multirow[t]{2}{*}{ Dead trees $(\mathrm{A}+\mathrm{B}+\mathrm{C})$} & All & 143 & 0.97 (n.s.) & 160 & $1.22(0.016)$ & 149 & 1.09 (n.s.) \\
\hline & Canopy trees & 58 & 0.93 (n.s.) & 45 & 1.05 (n.s.) & 42 & 0.98 (n.s.) \\
\hline \multirow[t]{2}{*}{ Dead trees $(\mathrm{A})$} & All & 20 & $1.20(0.018)$ & 17 & $1.43(0.001)$ & 14 & $1.27(0.01)$ \\
\hline & Canopy trees & 9 & 1.03 (n.s.) & 2 & 0.98 (n.s.) & 1 & 0.98 (n.s.) \\
\hline \multirow[t]{2}{*}{ Dead trees $(\mathrm{B})$} & All & 64 & 1.13 (n.s.) & 49 & $1.23(0.013)$ & 71 & 1.16 (n.s.) \\
\hline & Canopy trees & 28 & 1.01 (n.s.) & 15 & $1.22(0.02)$ & 22 & 1.03 (n.s.) \\
\hline \multirow[t]{2}{*}{ Dead trees $(\mathrm{C})$} & All & 59 & $1.15(0.05)$ & 94 & $1.43(0.001)$ & 64 & $1.48(0.001)$ \\
\hline & Canopy trees & 21 & 0.96 (n.s.) & 28 & $1.17(0.038)$ & 18 & 1.04 (n.s.) \\
\hline
\end{tabular}

Explanation: given random distribution, a ratio of 1 is expected. Significantly higher values indicate aggregated distributions; significantly lower values indicate regular distributions. The significance levels of the one-sided tests are given in brackets. The size classes are as follows: all trees- $d_{1.3} \geq 7 \mathrm{~cm}$ (15 cm for dead trees); under-canopy trees- $d_{1.3} \geq 7 \mathrm{~cm}\left(15 \mathrm{~cm}\right.$ for dead trees) and $d_{1.3}<25 \mathrm{~cm}$; canopy trees$d_{1.3} \geq 50 \mathrm{~cm}$

calculated for Stand II, in which the highest number of small trees was recorded. The frequency distributions of $\mathrm{VAR}_{\mathrm{h}}$ for single sample plots are as shown in Fig. $4 \mathrm{a}, \mathrm{b}$. The mean values ranged between 0.43 and 0.57 and were lower than the values calculated for each entire stand. In general, the highest frequency occurred in the sample plots with index values between 0.25 and 0.75 , that is, the plots characterised by bell-shaped or reverse J-shaped height distributions. The fraction of plots with low tree height variation and close to a one-layered structure (i.e. with $\mathrm{VAR}_{\mathrm{h}}<20$ ) was between 12 and $22 \%$.

In all three stands, the spatial distribution of $\mathrm{VAR}_{\mathrm{h}}$ was random (i.e. the $U$ values were between -0.25 and 0.52 ).
As shown in Fig. 4c, d, despite some inter-stand differences, in all cases, the variation coefficient of $\mathrm{VAR}_{\mathrm{h}}$ decreased strongly as the spatial scale increased up to about 0.5-1.0 ha, after which it decreased more slowly.

\section{Discussion}

Inter-stand variability

Given the variation in species composition (e.g. partitions of beech in the stand basal area of 44 and $83 \%$ ) and 
Table 4 Deviations between the empirical variance estimates and the expectations under random arrangement of live and dead trees defined by the $U$ value in the distance range between 20 and $200 \mathrm{~m}$

\begin{tabular}{llccc}
\hline Live/dead trees (decay class) & Size categories & Stand I & Stand II & Stand III \\
\hline Live trees & All & $1.86(20-80)$ & $2.30(20)$ & $1.75(20)$ \\
& Under-canopy trees & $1.98(20-80)$ & $1.76(20)$ & -0.41 \\
& Canopy trees & -0.62 & -0.50 & $1.97 / 1.32(60 / 100-200)$ \\
Dead trees (A + B + C) & All & $1.35(20)$ & -0.60 & $1.70(20-40)$ \\
& Canopy trees & -0.71 & -0.62 & 0.80 \\
Dead trees (A) & All & 0.11 & -0.28 & $-1.42(40-80)$ \\
& Canopy trees & $-1.15(60-200)$ & $-1.18(60-140)$ & $1.74(20-80)$ \\
Dead trees (B) & All & $1.32(20-180)$ & -0.52 & $1.20(40-160)$ \\
& Canopy trees & -0.03 & $1.28 / 1.15(40 / 100-120)$ & 0.10 \\
Dead trees (C) & All & 0.22 & 0.74 & -0.34 \\
\hline
\end{tabular}

Explanation: given random distribution, a value of 0 is expected. Values higher than 1 indicate a significant deviation towards aggregated patterns; values lower than -1 indicate a significant deviation towards regular patterns at the 0.05 significance level. Intermediate values indicate a (not statistically significant) tendency towards aggregated/regular patterns. For an exact definition of the $U$ value, see the Methods section. The distance range for which significant departures from randomness were found is in brackets (with the separate ranges denoted by a solidus). The size classes are as in Table 3

Fig. 3 Empirical frequency distributions of the basal area of live trees $\mathrm{BA}_{\mathrm{L}}(\mathbf{a})$ and dead trees $\mathrm{BA}_{\mathrm{D}}(\mathbf{b})$ on sample plots of 0.015 ha and the fitted models. To increase model generality, the data from the present study were combined with those from the Łabowiec project (Paluch 2007; denoted as Stand IV). The models were then used to simulate the frequency distributions of the basal area of live trees (c) and dead trees (d) on plots of different areas and to estimate the variation in the basal area dependent on plot area (e)
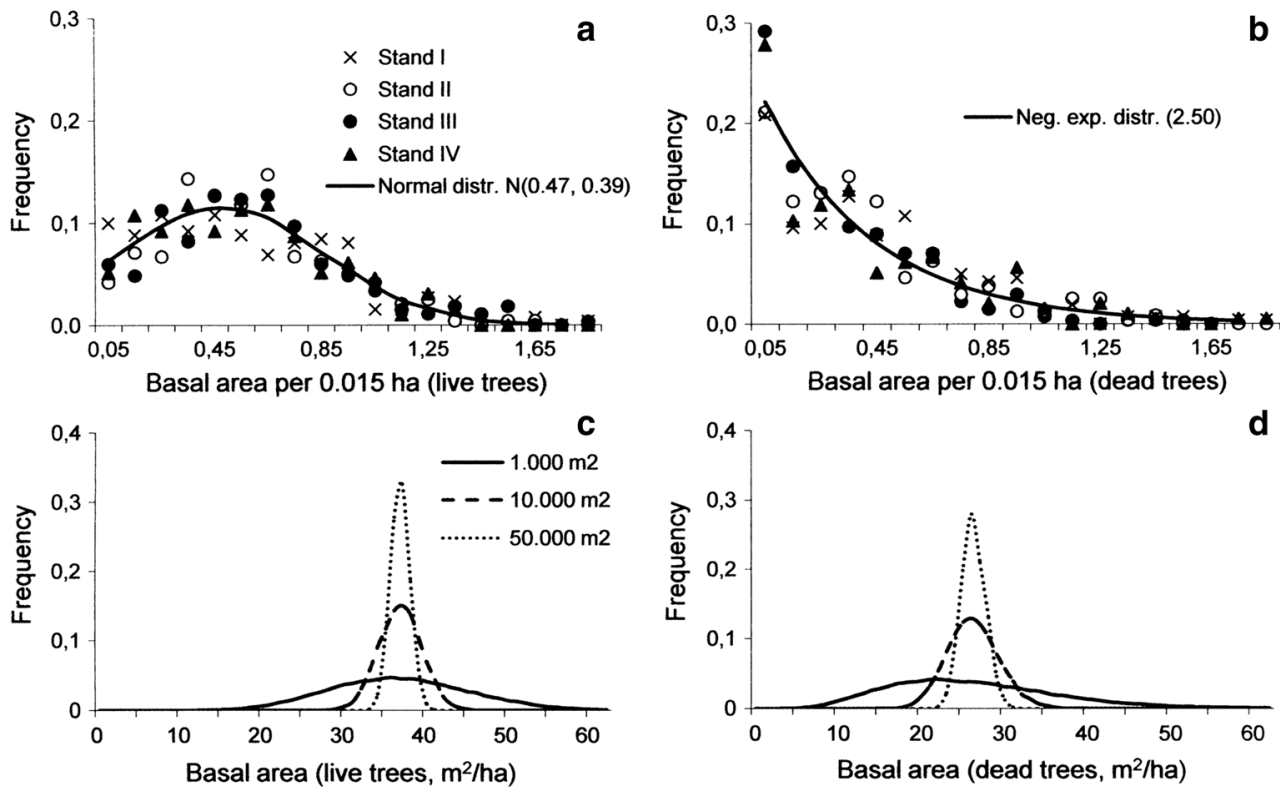

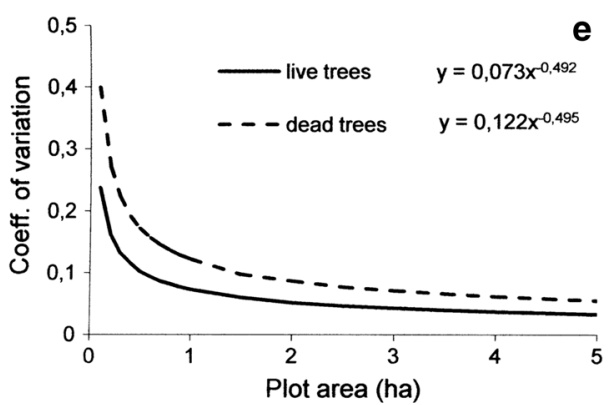

efficiency of space utilisation (about 1.5 higher in the conifers than in beech), the differences identified in stand basal area (between 36.1 and $38.4 \mathrm{~m}^{2} / \mathrm{ha}$ ) seem surprisingly small. That is, instead of the expected association between increasing conifer partition and increasing stand volume (Korpel' 1993; Holeksa et al. 2009), this 
Table 5 Deviations between the empirical variance estimates and the expectations under random arrangement of the basal area of live trees $\left(\mathrm{BA}_{\mathrm{L}}\right)$ and dead trees $\left(\mathrm{BA}_{\mathrm{D}}\right)$ defined by the $U$ value in the distance range between 20 and $200 \mathrm{~m}$

\begin{tabular}{lllll}
\hline $\begin{array}{l}\text { Live/dead } \\
\text { trees }\end{array}$ & $\begin{array}{l}\text { Size } \\
\text { categories }\end{array}$ & Stand I & $\begin{array}{l}\text { Stand } \\
\text { II }\end{array}$ & Stand III \\
\hline Live trees & All trees & $\begin{array}{c}-1.01 /-1.08 \\
(60 / 160)\end{array}$ & 0.41 & -0.11 \\
& & $\begin{array}{l}(1.14 /-1.26 \\
\text { Canopy } \\
\text { trees }\end{array}$ & -0.07 & -0.36 \\
& $(60-80 / 160)$ & & \\
Dead trees & $\begin{array}{c}\text { All trees } \\
\text { Canopy } \\
\text { trees }\end{array}$ & $-1.05(60-100)$ & -0.39 & $1.13(40-80)$ \\
& & & -0.54 & $1.02(80)$ \\
\hline
\end{tabular}

Explanation: see Table 4

study identified similar levels of stand basal area, suggesting that in natural stands, both species vulnerability to disturbances and the frequency and intensity of disturbance events may strongly modify basal area levels. In fact, Nagel and Diaci (2006) have provided clear evidence that a strong storm caused greater damage to fir than to beech in a primeval stand. A higher variation in basal area of dead trees was found between Stand III (20.2) and Stand I $\left(28.0 \mathrm{~m}^{2} / \mathrm{ha}\right)$, but this observation may be explainable by the approximately twice-as-rapid decay of beech wood compared with spruce or fir wood (Korpel' 1993; Lombardi et al. 2008; Müller-Using and Bartsch 2009).

Despite congruously shaped diameter distributions, which matched the rotated sigmoid form common in other beech-dominated primeval stands (e.g. Dziewolski 1991; Leibundgut 1993; Przybylska et al. 1995; Piovesan et al. 2005; Westphal et al. 2006; Alessandrini et al. 2011), the stands differed visibly in stem density (between 288 and 682 live trees per ha), a variation attributable primarily to under-canopy trees. The differences in the number of under-canopy trees influenced the differentiation index values, which were highest in Stand I, with the smallest number of under-canopy trees, and lowest in Stand II, with the highest number. For dead trees, in contrast, there was considerable similarity in diameter distribution and stem density.

In general, the range of stand volume level that might be anticipated based on our results corresponds with the data collected in large-area inventories ( $>3 \mathrm{ha}$ ) in other closeto-primeval West Carpathian forest, including Pieniny
Fig. 4 Empirical frequency distributions of the differentiation index $\left(\mathrm{VAR}_{\mathrm{h}}\right)$ for the sample plots 0.015 ha in area and the fitted model $(\mathbf{a}, \mathbf{b})$. The empirical diameter distributions from these small plots were then used to simulate the frequency distributions of $\mathrm{VAR}_{\mathrm{h}}$ on plots of different areas (c, d) and to estimate the variation in $\mathrm{VAR}_{\mathrm{h}}$ dependent on plot area $(\mathbf{e})$
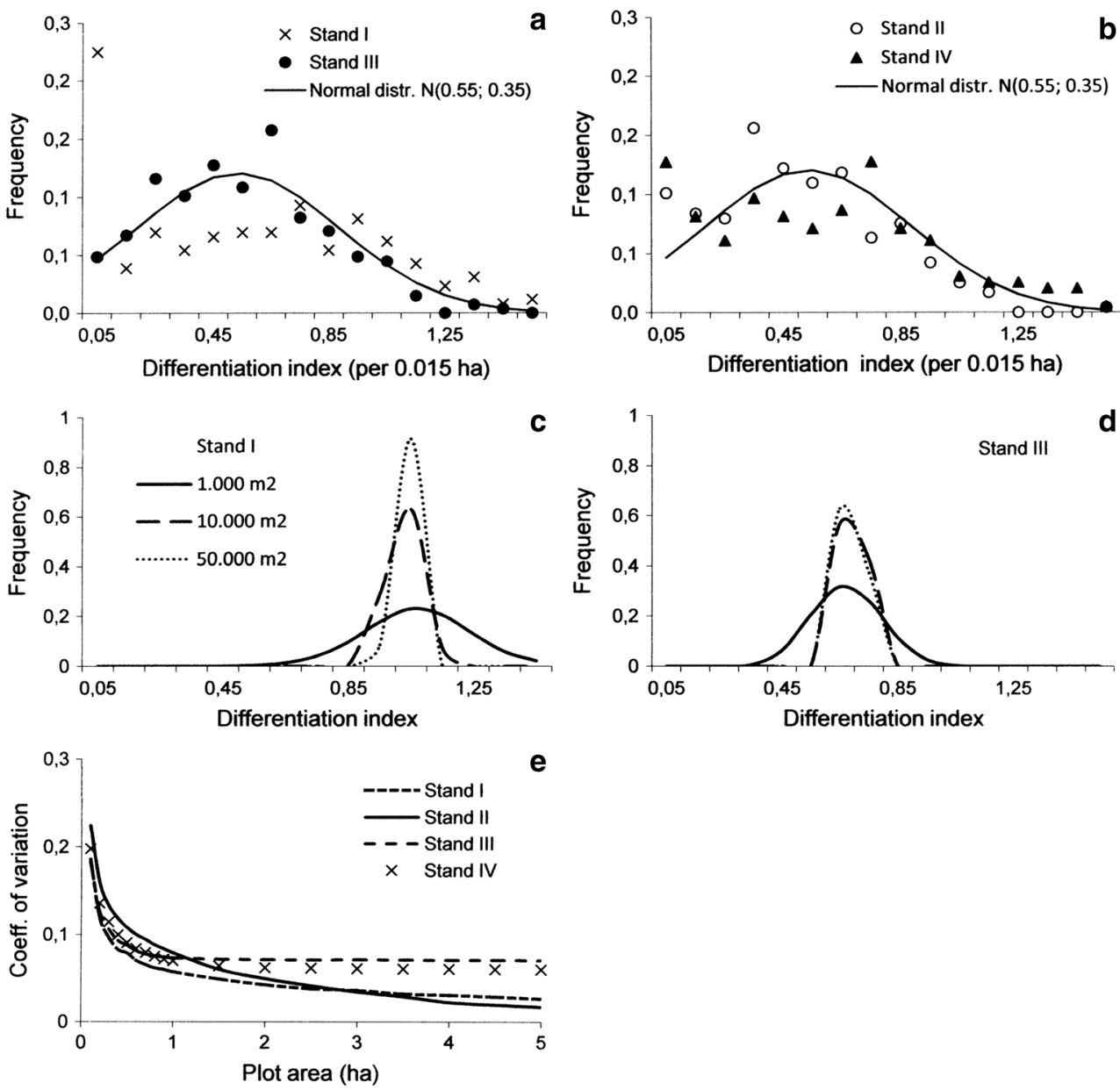

Differentiation index 
National Park (Dziewolski 1991), Vyhorlatský prales reserve (Drössler 2006), Oszast reserve (Holeksa et al. 2009), Gorce National Park (Przybylska et al. 1995), and Salajka reserve (Vyskot 1968). Admittedly, some authors have reported higher stand volume levels between 550 and $850 \mathrm{~m}^{3} /$ ha (see Holeksa et al. 2009; Motta et al. 2011), but these results were obtained in a wide range of geographic locations (Albania, Czech Republic, Italy, Slovakia, Slovenia, Ukraine), the measurements represented different sized areas, and both site conditions and the proportion of tree species in the stands differed substantially (e.g. a partition of beech between 20 and $100 \%$; Holeksa et al. 2009). Comparing the data is thus very problematic.

\section{Patchy versus random patterns}

The spatial distribution of live and dead canopy trees was regular on the single plot scale but random on the larger spatial scales. For relevant spatial scales, the variation in the basal area of live and dead trees was also generally random and thus inconsistent with the patch-mosaic assumption. Minor deviations towards regularity or aggregation found in some larger distance ranges may not weaken this general conclusion because in the case of "patchy" patterns, the strongest association is to be expected between the closest stand patches. The distribution pattern of dead canopy trees suggests that on the scale of single-tree influence, mortality is driven by competitive interactions, whereas on larger scales, it is primarily the result of spatially random disturbances. One important implication of this finding is that merging small patches of an area corresponding to the average parcel of canopy trees into higher order units (i.e. development stages/phases) is not justified because their developmental trajectories conditioned by canopy gap formation are at least partly asynchronous and independent.

On the several dozen meter scale, aggregated patterns appear frequently in the cases of under-canopy trees and regeneration (data not published), the only two attributes to show spatial variability conformant with the patch-mosaic paradigm. Although this present study did not directly address this question, these aggregated patterns could be expected to arise as a result of increased small tree survival in stand patches with a loosened canopy, reduced survival in stand patches formed by dense sub-canopy/under-canopy trees, inter-stand habitat variability, and/or heterogeneous seed rain.

\section{Generalised model of intra-stand variability}

All the stands studied were characterised by a fine-grained texture and very similar patterns of intra-stand variation in the differentiation index $\left(\mathrm{VAR}_{\mathrm{h}}\right)$ and the basal area of live and dead trees $\left(\mathrm{BA}_{\mathrm{L}}\right.$ and $\mathrm{BA}_{\mathrm{D}}$, respectively). The regression model $\left(y=a x^{b}\right)$ of variation in the basal area of live trees in relation to plot size proposed in this study is very similar to that fitted by Král et al. (2010a) ( $a=0.073$ vs. $0.80, b=-0.49$ vs. -0.47$)$ for other three beech-dominated natural forests from the region of Central Europa. These matching results suggest that the relations identified are characterised by a considerable generality.

The similar patterns of intra-stand variability raise the crucial question of whether they are constant along the temporal scale or fluctuate under the influence of disturbing events. In fact, disturbances of moderate intensity in larger areas of close-to-natural stands of similar species composition have been recorded in several studies (Splechtna et al. 2005; Firm et al. 2009; Trotsiuk et al. 2012). On the other hand, the disturbances leading to more or less stand damage are quite frequent in the site and climatic conditions of the region. Zajączkowski (1991), for example, listed at least 18 episodes of significant wind or snow damage in the managed stands of the Western Carpathians between 1945 and 1988. Likewise, Nagel and Diaci (2006) showed that storms with winds strong enough to cause intermediate damage occur rather frequently in south-eastern Europe. These observations suggest that the influence of such phenomena may be rather permanent and homogenous.

The stands of the beech-fir-spruce forests growing on fertile sites also have significant potential to "buffer" the effect of disturbances. Assuming an average annual stand basal area increment of about $0.35 \mathrm{~m}^{2}$ per ha (Dziewolski and Rutkowski 1991; Przybylska et al. 1995; Jaworski and Kołodziej 2002; Jaworski and Paluch 2002; Jaworski et al. 2007), even if severe disturbances reduce the level of the stand basal area by half, it will fully recover in five to six decades. To underscore the severity of such hypothetical disturbances, it should be noted that the average rate of stand basal area loss per decade may be estimated at about $10 \%$ (a basal area increment of about $3.5 \mathrm{~m}^{2} /$ ha and a stand basal area of about $36 \mathrm{~m}^{2} / \mathrm{ha}$ ). Nagel and Diaci (2006), for instance, described a primeval mixed fir-beech stand in Slovenia in which the intermediate disturbances caused by two strong summer storms with unusually intense winds reduced the stand basal area by only 10-13\%. These damage levels are comparable to the results reported in other studies for such wind disturbances in temperate forests (Webb 1989; Woods 2004). In sum, although several arguments seemingly support the generality of the variation in the structural attributes of primeval mixed forests modelled in this study, ultimately the validity of the relations identified must be assessed in the light of accumulating empirical data.

Implications for stand dynamics theory

Based on the results of this current study, the attribute of patchiness, a crucial assumption of the developmental 
cycle hypothesis, applies only to the spatial distribution of trees in the lower stand layer. In the case of tree mortality in the canopy zone, a key factor in shaping intra-stand stand texture, no evidence was found of a patchy spatial pattern. Hence, the patch-mosaic hypothesis and its related developmental cycle seem inappropriate for describing the dynamics of the beech-fir-spruce stands in the Western Carpathians.

The study results also indicate that in small patch areas, the distribution of the basal area of live trees is well approximated by the normal distribution. Assuming that on a temporal scale, this distribution changes little, this finding suggests that in the forest formation studied, disturbances of minor intensity prevail that rarely reduce the stand basal area to a close-to-zero level even in small stand patches. Moreover, the bell-shaped distribution of the basal area further suggests that this characteristic's temporal variation cannot be modelled by the sinusoidal curve proposed by Korpel' (1993), which has a constant amplitude and interval, because in such a case, the stand basal area distribution is likely to have two modal values at its extreme points. Rather, a medium value mode like that identified here implies a model in which extreme values are rare and disturbances frequent but rapidly balanced by biomass increment.

On the single plot spatial scale-that is, on a scale corresponding to the average parcel of canopy trees-the stand structure showed considerable variability. This observation strongly suggests that the complex structure of the forests studied may not be the result of a simple combination of small patches in different stages of canopy gap closing process as anticipated by the "classical" gap dynamics theory (Shugart 1984; Remmert 1991). Rather, under conditions of permanent and homogenous disturbances, structured forests develop that tend to have a wellformed mid-canopy tree layer, meaning that trees may need to survive several shading periods and release events before they reach the upper tree layer.

\section{Acknowledgments This work was supported by the National Sci- ence Centre, Poland (on Contract No. 2012/07/B/NZ9/00953). Two anonymous reviewers are greatly acknowledged for their valuable comments and making the manuscript more concise and informative. We wish to thank students from the Faculty of Forestry at the Agri- cultural University in Cracow, who provided support to our team in the field measurements.}

Open Access This article is distributed under the terms of the Creative Commons Attribution License which permits any use, distribution, and reproduction in any medium, provided the original author(s) and the source are credited.

\section{References}

Alessandrini A, Biondi F, Di Filippo A, Ziaco E, Piovesan G (2011) Tree size distribution at increasing spatial scales converges to the rotated sigmoid curve in two old-growth beech stands of the Italian Apennines. For Ecol Manag 262:1950-1962

Bauhus J, Puettmann K, Messier C (2009) Silviculture for old-growth attributes. For Ecol Manag 258:525-537

Christensen M, Hahn K, Mountford EP, Ódor P, Standovár T, Rozenbergar D, Diaci J, Wijdeven S, Meyer P, Winter S, Vrška $\mathrm{T}$ (2005) Dead wood in European beech (Fagus sylvatica) forest reserves. For Ecol Manag 210:267-282

Commarmot B, Bachofen H, Bundziak Y, Bürgi A, Ramp B, Shparyk Y, Sukhariuk D, Viter R, Zingg A (2005) Structures of virgin and managed beech forests in Uholka (Ukraine) and Sihlwald (Switzerland): a comparative study. For Snow Landsc Res 79:45-56

Cressie NAC (1991) Statistics for spatial data. Wiley, New York

Drössler L (2006) Struktur und Dynamik von zwei Buchenurwäldern in der Slowakei. Dissertation, Georg-August-Universität, Göttingen

Dziewolski J (1991) Naturalny rozwój drzewostanów w Pienińskim Parku Narodowym w okresie 51 lat (1963-1987). Ochr Przyr 49:111-128

Dziewolski J, Rutkowski B (1991) Tree mortality, recruitment and increment during the period 1969-1986 in reserve at Turbacz in the Gorce Mountains. Fol For Pol ser A 31:37-48

Emborg J, Christensen M, Heilmann-Clausen J (2000) The structural dynamics of Suserup Skov, a near natural temperate deciduous forest in Denmark. For Ecol Manag 126:173-189

Firm D, Nagel TA, Diaci J (2009) Disturbance history and dynamics of an old-growth mixed species mountain forest in the Slovenian Alps. For Ecol Manag 257:1893-1901

Grundner F, Schwappach A (1952) Massentaffeln zur Bestimmung des Holzgehaltes stehender Waldbäume und Waldbestände. Parey, Berlin

Holeksa J, Saniga M, Szwagrzyk J, Czerniak M, Staszyńska K, Kapusta P (2009) A giant tree stand in the West Carpathians: an exception or a relic of formerly widespread mountain European forests? For Ecol Manag 257:1577-1585

Homolka M, Heroldová M (2003) Impact of large herbivores on mountain forest stands in the Beskydy Mountains. For Ecol Manag 181:119-129

Jaworski A (2004) Badania nad budową, dynamiką i strukturą lasów o charakterze pierwotnym i ich znaczenie w kształtowaniu modelu gospodarki leśnej w górach. Roczniki Bieszczadzkie 12:103-139

Jaworski A, Kołodziej Z (2002) Natural loss of trees, recruitment and increment in stands of primeval character in selected areas of the Bieszczady Mountains National Park (south-eastern Poland). J For Sci 48:141-149

Jaworski A, Paluch J (2002) Factors affecting the basal area increment of the primeval forests in the Babia Góra National Park, Southern Poland. Forstw Centralbl 121:97-108

Jaworski A, Kołodziej Z, Łapka M (2007) Mortality, recruitment, and increment of trees in the Fagus-Abies-Picea stands of a primeval character in the lower mountain zone. Dendrobiology 57:15-26

Kenderes K, Král K, Vrška T, Standovár T (2009) Natural gap dynamics in a Central European mixed beech-spruce-fir old growth forest. Ecoscience 16:39-47

Korpel' $\breve{S}$ (1993) Die Urwälder der Westkarpaten. Gustav Fisher Verlag, Stuttgart

Král K, Janik D, Vrška T, Adam D, Hort L, Unar P, Šamonil P (2010a) Local variability of stand structural features in beech dominated natural forests of Central Europe: implications for sampling. For Ecol Manag 260:2196-2203

Král K, Vrška T, Hort L, Adam D, Šamonil P (2010b) Developmental phases in a temperate natural spruce-fir-beech forest: determination by a supervised classification method. Eur J For Res 129:339-351

Kucbel S, Jaloviar P, Saniga M, Vencurik J, Klimaš V (2010) Canopy gaps in an old-growth fir-beech forest remnant of Western Carpathians. Eur J For Res 129:249-259 
Leibundgut H (1993) Europäische Urwälder. Paul Haupt, Bern

Lombardi F, Cherubini P, Lasserre B, Tognetti R, Marchetti M (2008) Tree rings used to assess time since death of deadwood of different decay classes in beech and silver fir forests in the central Appenines (Molise, Italy). Can J For Res 38:821-833

Mayer H (1986) Europäische Urwälder. UTB, Fischer Verlag, Stuttgart

Mayer H, Ott E (1991) Gebirgswaldbau. Schutzwaldpflege, Gustav Fischer

Meyer P, Tabaku V, von Lüpke B (2003) Die Struktur albanischer Rotbuchen-Urwäldern - Ableitungen für eine naturnahe Buchenwirtschaft. Forstw Centralbl 122:47-58

Motta R, Berretti R, Castagneri D, Dukič V, Garbarino M, Govedar Z, Lingua E, Maunaga Z, Meloni F (2011) Toward a definition of the range of variability of central European mixed Fagus-AbiesPicea forests: the nearly steady-state forest of Lom (Bosnia and Herzegovina). Can J For Res 4:1871-1884

Müller-Using S, Bartsch N (2009) Decay dynamic of coarse and fine woody debris of a beech (Fagus sylvatica $\mathrm{L}$.) forest in Central Germany. Eur J For Res 128:287-296

Nagel TA, Diaci J (2006) Intermediate wind disturbance in an old growth beech-fir forest in southeastern Slovenia. Can J For Res 36:629-638

Nagel TA, Svoboda M (2008) Gap disturbance regime in an oldgrowth Fagus-Abies forest in the Dinaric Mountains, Bosnia-Herzegovina. Can J For Res 38:2728-2737

Nagel TA, Svoboda M, Diaci J (2006) Regeneration patterns after intermediate wind disturbance in an old growth Fagus-Abies forest in southeastern Slovenia. For Ecol Manag 226:268-278

Otto HJ (1994) Waldökologie. Eugen Ulmer Verlag, Stuttgart

Paluch J (2007) The spatial pattern of a natural European beech (Fagus sylvatica L.) —silver fir (Abies alba Mill.) forest: a patchmosaic perspective. For Ecol Manag 253:161-170

Paszyński J, Niedzwiedź T (1999) Klimat. In: Starkel L (ed) Geografia Polski. Środowisko przyrodnicze, PWN, Warszawa, pp 288-343

Piovesan G, Di Filippo A, Alessandrini A, Biondi F, Schirone B (2005) Structure, dynamics and dendroecology of an old-growth Fagus forest in the Apeninnes. J Veg Sci 16:13-28

Podlaski R (2008) Dynamics in Central European near-natural AbiesFagus forests: does the mosaic-cycle approach provide an appropriate model? J Veg Sci 19:173-182

Przybylska K, Fujak J, Myćka P (1995) Dynamika zmian zasobów leśnych w rezerwacie "Dolina Łopusznej" Gorczańskiego Parku Narodowego w okresie kontrolnym 1982-1992. Parki Nar Rez Przyr 14(3):23-31

Remmert H (1991) The mosaic-cycle concept of ecosystems: an overview. In: Remmert $\mathrm{H}$ (ed) The mosaic-cycle concept of ecosystems, Ecological Studies 85:1-21

Roženbergar D, Mikac S, Anić I, Diaci J (2007) Gap regeneration patterns in relationship to light heterogeneity in two old-growth beech: fir forest reserves in South East Europe. Forestry 80:431-443

Šebková B, Šamonil P, Janik D, Adam D, Král K, Vrška T, Hort L, Unar P (2011) Spatial and volume patterns of an unmanaged submontane mixed forest in Central Europe: 160 years of spontaneous dynamics. For Ecol Manag 262:873-885

Shugart HH (1984) A theory of forest dynamics. Springer Verlag, New York

Splechtna BE, Gratzer G, Black BA (2005) Disturbance history of a European old-growth mixed-species forest: a spatial dendroecological analysis. J Veg Sci 16:511-522

Standovár T, Kenderes K (2003) A review on natural stand dynamics in beechwoods of East Central Europe. Appl Ecol Environ Res $1: 19-46$

Szwagrzyk J, Czerwczak M (1993) Spatial patterns of trees in natural forests of East-Central Europe. J Veg Sci 4:469-476

Szwagrzyk J, Szewczyk J (2001) Tree mortality and effects of release from competition in an old-growth Fagus-Abies-Picea stand. J Veg Sci 12:621-626

Szwagrzyk J, Szewczyk J, Bodziarczyk J (1997) Spatial variability of a natural stand in the Babia Góra National Park. Fol For Pol ser A 39:61-78

Trotsiuk V, Martina L, Hobi ML, Commarmot B (2012) Age structure and disturbance dynamics of the relic virgin beech forest Uholka (Ukrainian Carpathians). For Ecol Manag 265:181-190

Veen P, Fanta J, Raev I, Biriş I-A, de Smidt J, Maes B (2010) Virgin forests in Romania and Bulgaria: results of two national inventory projects and their implications for protection. Biodivers Conserv 19:1805-1819

von Oheimb G, Westphal Ch, Tempel H, Härdtle W (2005) Structural pattern of a near-natural beech forest (Fagus sylvatica) (Serrahn, north-east Germany). For Ecol Manage 212:253-263

Vrška T, Adam D, Hort L, Kolar T, Janik D (2009) European beech (Fagus sylvatica L.) and silver fir (Abies alba Mill.) rotation in the Carpathians: a developmental cycle or a linear trend induced by man? For Ecol Manag 258:347-356

Vyskot M (1968) Porostni struktura a prirozena obnova v pralesovite rezervaci Bumbálka. Lesnický Časopis 14:607-619

Webb SL (1989) Contrasting windstorm consequences in 2 forests, Itasca State Park, Minnesota. Ecology 70:1167-1180

Westphal Ch, Tremer N, von Oheimb G, Hansen J, von Gadow K, Härdtle W (2006) Is the reverse J-shaped distribution universally applicable in European virgin beech forests? For Ecol Manag 223:75-83

Winter S (2012) Forest naturalness assessment as a component of biodiversity monitoring and conservation management. Forestry 85:293-304

Winter S, Brambach F (2011) Determination of a common forest life cycle assessment method for biodiversity evaluation. For Ecol Manag 262:2120-2132

Woods KD (2004) Intermediate disturbance in a late-successional hemlock-northern hardwood forest. J Ecol 92:464-476

Zajączkowski J (1991) Odporność lasu na szkodliwe działanie wiatru i śniegu. Wydawnictwo Świat, Warszawa

Zeibig A, Diaci J, Wagner S (2005) Gap disturbance patterns of a Fagus sylvatica virgin forest remnant in the mountain vegetation belt of Slovenia. For Snow Landsc Res 79:69-80 